\title{
Evaluating the Intercropping of Millet with Cowpea for Forage Yield and Quality
}

\author{
Naveed Islam1, Muhammad Shahid Ibni Zamir1*, Shan Mohi Ud Din1, \\ Umer Farooq1', Haseeb Arshad1, Aqib Bilal'2, Muhammad Talha Sajjad1 \\ ${ }^{1}$ Department of Agronomy, University of Agriculture, Faisalabad, Pakistan \\ ${ }^{2}$ Department of Botany, University of Agriculture, Faisalabad, Pakistan \\ Email: ^ibnizamir@uaf.edu.pk
}

How to cite this paper: Islam, N., Zamir, M.S.I., Din, S.M.U., Farooq, U., Arshad, H., Bilal, A. and Sajjad, M.T. (2018) Evaluating the Intercropping of Millet with Cowpea for Forage Yield and Quality. American Journal of Plant Sciences, 9, 1781-1793. https://doi.org/10.4236/ajps.2018.99130

Received: April 21, 2018

Accepted: August 4, 2018

Published: August 7, 2018

Copyright () 2018 by authors and Scientific Research Publishing Inc. This work is licensed under the Creative Commons Attribution International License (CC BY 4.0)

http://creativecommons.org/licenses/by/4.0/

\begin{abstract}
A field study was scheduled to estimate the impact of intercropping of pearl millet with cowpea on forage yield and quality at Agronomy Research Farm, University of Agriculture, Faisalabad. It was done in kharif season 2016. Randomized complete block design was used to conduct this experiment. It has three replications. The size of net plot is $3.6 \mathrm{~m} \times 6 \mathrm{~m}$. It comprised of five treatments $\left(\mathrm{T}_{1}=\right.$ one row of millet alternating with one row of cowpea (1M:1C), $\mathrm{T}_{2}=$ two rows of millet alternating with one row of cowpea (2M:1C), $\mathrm{T}_{3}$ = one row of millet alternating with two rows of cowpea $(1 \mathrm{M}: 2 \mathrm{C}), \mathrm{T}_{4}=$ sole millet, $\mathrm{T}_{5}=$ sole cowpea). We found that intercropping significantly effected the yield and quality of forage. Intercropping system had significant effects on nutritive value of forage crop. Within various treatments of intercropping, it is evident that treatment $T_{2}$ (two rows of millet alternating with one row of cowpea) gives maximum total dry matter yield $\left(9.68 \mathrm{t} \mathrm{ha}^{-1}\right)$. It was then tracked by treatment $T_{1}$ (one row of millet alternating with one row of cowpea) and treatment $T_{3}$ (one row of millet alternating with two rows of cowpea) producing dry matter yield (9.07 $\mathrm{t} \mathrm{ha}^{-1}$ and $8.33 \mathrm{t} \mathrm{ha}^{-1}$, respectively). Based on high grain and suitable environmental condition, intercrop productivity compared to sole crop could be selected for improving the productivity of millet/cowpea mixture in the Punjab.
\end{abstract}

\section{Keywords}

Intercropping, Forage, Quality, Yield, Crop, Productivity

\section{Introduction}

Pearl millet is also called bajra. It is from poaceae family and cultivated for fo- 
rage purpose and also for grain purpose, too. This is a best food during summer season for animals. Usually, it is grown in rain fed areas of Punjab. It is good tolerant of heat and water shortage. It is good in producing a lot of dry matter; that's why it is most liked by farmers as well as animals, too. Hay and silage are also made from this crop. It has a delicious taste so most of the animals like to eat this fodder. If we talk about its grain, then grains can be in poultry feed [1]. Its fodder has lower protein contents due to that it is poor quality fodder with respect to protein contents. If we intercrop millet with any legume crop like cowpea then its quality can be made better due to enhanced protein percentage [2].

Cowpea (Vigna unguiculata) is very important legume specie. It also has good tolerance against water shortage. It loves warm-season to grow. As we know that it is a legume crop so it has ability to fix atmospheric nitrogen. It is well adapted to soils. Soils in which there is major portion is sand around $85 \%$ and less than $0.2 \%$ organic matter is present, in that soil it performs best [3]. It can be grown in cool and shady areas and with millet, maize and cotton.

Legumes are believed to be very good nitrogen fixers; that's why legumes are considered good and if they are grown with other non-leguminous forage then it gives good quality forage. These are also believed to reduce the cost of nitrogen application as they are already fixing nitrogen from atmosphere [4]. It's intercropping with non-leguminous crops not only a reason of increase in production of forage but quality is also enhanced due to high level of protein level then cereals [5]. Cereals are also grown in tropical areas with legumes [6]. This practice is also done in rain fed areas too of the world [7]. This practice of intercropping has a major effect in production of food in both developed and developing areas [8]. We get higher yields in intercropping system than sole system [9].

Growing of legumes with cereals also helps in improving the overall condition of soil by nitrogen fixation [10]. Fixed nitrogen by the legumes then transferred to cereals growing with legumes that are also much essential to crops [11]. Sowing of mixed seed increases the yield, and quality if done with legumes [12]. Main purpose of this practice is to get higher yield by using all sources that are available at that time which may be not used by a single crop fully.

Among the critical factors on which crop productivity depends, row spacing is one among those [13]. [14] said when sorghum is grown with cowpea then it gives maximum fresh forage yield and dry matter yield of sorghum. Yield of any crop, if we talk about pearl millet is increased up to a certain stage after which it decreases [15]. In case of delay in harvesting fresh and dry matter yield and fiber percentage improved but protein contents and ash contents decreased [16]. But with early maturity there is decreasing trend in protein contents and enhances the acid fiber contents [17].

[18] also did an experiment of intercropping. He intercropped maize with cluster bean (Cymopsis tetragonobola), cowpea and French bean (Phaseolus vulgaris) with different ratios (1:1,2:2, and 1:2). There was a distance of $60 \mathrm{~cm}$ in 
uniform rows and a distance of $40 \mathrm{~cm}$ in paired rows. Maize is sown with $90 \mathrm{~cm}$ distance among two paired rows. Plant to plant distance of $25 \mathrm{~cm}$ was maintained. He concluded that 2:2 row ratio of maize and French bean was better than other in case of money advantages. [19] conducted an experiment with different plant densities and found that there is no such a great variation in case of maize yield. He kept 50,000 plants per hectare of maize in double rows while there is a single row of French bean with 40,000 plants per hectare.

[20] found when maize was grown in combination with groundnut at 2:2 row ratios, then maize was found to show larger maize grain equivalent yield as compared to its sole crop. But in contrary [21] found that when sorghum and cowpea was sown together then they show higher yields of grain and straw in sole system than in their intercropping system. [22] said that when cowpea is grown with cluster bean then this combination increased the digestive value of fodder and also increases the fertility of the soil. Main purpose of this missed cropping system is also to fully and efficiently use the resources that are available which a single crop cannot use efficiently. [23] also reported the overall potential of intercropping maize with legumes in the semiarid region of Ethiopia. They uses following treatments for maize and legumes. For maize 4 treatments are used. They use 4 planting densities for maize which were $(0,20,35,50$ thousand plants per hectare). For legumes treatments of planting time was used. Legumes were planted at two times, first with the sowing of maize and second are after 20 days. They uses legumes of two types, first is annul legumes of dual purpose like cowpea and lablab and second are forage legumes like centro and cassia. They showed yield profits of this intercropping system, they found that when maize is sown with legumes then it shows higher fresh forage yields and dry yields as compared to sole cropping system.

\section{Materials and Methods}

A field study is scheduled to estimate the impact of intercropping pearl millet with cowpea on forage yield and quality at Agronomy Research Farm, University of Agriculture, Faisalabad. It is done in kharif season 2016. Experiment is planned to conduct on a soil which is quite clay loam in nature. Faisalabad is a semi-arid region. It is located at $73^{\circ} \mathrm{E}$ and $31^{\circ} \mathrm{N}$ and at an elevation of $135 \mathrm{~m}$ above level of sea. Randomized complete block design is used to conduct this experiment. It has three replications and a net plot size is $3.6 \mathrm{~m} \times 6 \mathrm{~m}$. There are 12 rows in each plot. The experiment is comprised of 5 treatments given below.

$\mathrm{T}_{1}=$ one row of millet alternating with one row of cowpea (1M:1C);

$\mathrm{T}_{2}=$ two rows of millet alternating with one row of cowpea (2M:1C);

$\mathrm{T}_{3}=$ one row of millet alternating with two rows of cowpea (1M:2C);

$\mathrm{T}_{4}=$ sole millet;

$\mathrm{T}_{5}=$ sole cowpea.

The seed rate for pearl millet is $4-5 \mathrm{~kg} / \mathrm{ha}$ and for cowpea $12-15 \mathrm{~kg} / \mathrm{acre}$ is used. Pearl millet variety P-518 and cowpea variety PL-101 were sown in lines 
with the help of hand drill. Field was cultivated with cultivator 3 - 4 times and then planking was done to make the soil feasible for sowing. Seed was sown on 14th of May, 2016. All agronomic practices are considered as normal for all the treatments except those which were under study. The data which we have taken for different growth, yield and quality traits is examined statistically using Fisher's analysis of variance technique. Then least significance difference test (LSD) is applied at 5\% probability level to check the significance of treatment's mean [24].

\section{Results and Discussion}

The data presented in Table 1 and Table 2 proved that intercropping of pearl millet with cowpea significantly affected the Yield parameters such as plant Population, plant height $(\mathrm{m})$, Leaf area $\left(\mathrm{cm}^{2}\right)$, leaf to stem ratio, stem diameter $(\mathrm{cm})$, green forage yield pearl millet $\left(\mathrm{t} \mathrm{ha} \mathrm{h}^{-1}\right)$, green forage yield of cowpea $\left(\mathrm{t} \mathrm{ha} \mathrm{h}^{-1}\right)$, green forage yield pearl millet + cowpea $\left(\mathrm{t} \mathrm{ha}^{-1}\right)$, dry matter yield of pearl millet $\left(\mathrm{t} \mathrm{ha} \mathrm{a}^{-1}\right)$, dry matter yield $\left(\mathrm{t} \mathrm{ha}^{-1}\right)$ of mixed forage (pearl millet + cowpea) and dry

Table 1. Growth and yield related parameters of pearl millet as influenced by intercropping of millet with cowpea.

\begin{tabular}{cccccc}
\hline Treatments & Plant population & Plant height $(\mathrm{m})$ & Leaf area $\left(\mathrm{cm}^{2}\right)$ & leaf to stem ratio & Stem diameter $(\mathrm{cm})$ \\
\hline $\mathrm{T}_{1}$ & 44.00 & 243.00 & 2186 & 0.2200 & 1.12 \\
$\mathrm{~T}_{2}$ & 58.66 & 246.33 & 2250 & 0.1900 & 1.14 \\
$\mathrm{~T}_{3}$ & 29.66 & 241.00 & 2103 & 0.2633 & 1.08 \\
$\mathrm{~T}_{4}$ & 88.33 & 250.33 & 2415 & 0.1633 & 1.21 \\
LSD & 1.3729 & 2.4695 & 39.802 & 0.0233 & 0.0341 \\
F Value & $3996.47^{* *}$ & $32.80^{*}$ & $131.92^{* *}$ & $40.55^{* *}$ & $30.51^{\star}$ \\
\hline
\end{tabular}

${ }^{*}=$ Significant at $p \leq 0.05 ;{ }^{*}=$ Significant at $p \leq 0.01 ; \mathrm{T}_{1}=$ One row of millet alternating with one row of cowpea (1M:1C); $\mathrm{T}_{2}=\mathrm{Two}$ rows of millet alternating with one row of cowpea (2M:1C); $\mathrm{T}_{3}=$ One row of millet alternating with two rows of cowpea (1M:2C); $\mathrm{T}_{4}=$ Sole millet. Means not sharing the same letter in common differ significantly at $5 \%$ probability level.

Table 2. Growth and yield related parameters of pearl millet and cowpea as influenced by intercropping of millet with cowpea.

\begin{tabular}{|c|c|c|c|c|c|c|}
\hline Treatments & $\begin{array}{l}\text { Green forage } \\
\text { yield pearl } \\
\text { millet }\left(\mathrm{t} \mathrm{ha}^{-1}\right)\end{array}$ & $\begin{array}{l}\text { Green forage yield of } \\
\text { cowpea }\left(\mathrm{tha}^{-1}\right)\end{array}$ & $\begin{array}{c}\text { Green forage } \\
\text { yield pearl millet } \\
+ \text { Cowpea }\left(\mathrm{t} \mathrm{ha}^{-1}\right)\end{array}$ & $\begin{array}{l}\text { Dry matter yield of } \\
\text { pearl millet }\left(\mathrm{t} \mathrm{ha}^{-1}\right)\end{array}$ & $\begin{array}{l}\text { Dry matter yield } \\
\left(t \mathrm{ha}^{-1}\right) \text { of mixed } \\
\text { forage (pearl } \\
\text { millet + cowpea) }\end{array}$ & $\begin{array}{l}\text { Dry matter yield of } \\
\text { cowpea }\left(\mathrm{t} \mathrm{ha}^{-1}\right)\end{array}$ \\
\hline $\mathrm{T}_{1}$ & 22.06 & 16.73 & 38.80 & 5.44 & 9.07 & 3.62 \\
\hline $\mathrm{T}_{2}$ & 29.10 & 11.13 & 40.23 & 7.24 & 9.68 & 2.44 \\
\hline $\mathrm{T}_{3}$ & 14.62 & 22.30 & 36.90 & 3.48 & 8.33 & 4.84 \\
\hline $\mathrm{T}_{4}$ & 44.00 & - & 44.00 & 10.91 & 10.91 & - \\
\hline $\mathrm{T}_{5}$ & - & 33.53 & 33.53 & - & 7.26 & 7.26 \\
\hline LSD & 0.4374 & 0.3052 & 0.7557 & 0.4111 & 0.2517 & 0.1613 \\
\hline F Value & $9810.47^{\star *}$ & $11756.0^{* *}$ & $281.07^{\star *}$ & $706.23^{\star *}$ & $317.40^{* *}$ & $1956.73^{* *}$ \\
\hline
\end{tabular}

${ }^{*}=$ Significant at $p \leq 0.05 ;{ }^{*}=$ Significant at $p \leq 0.01 ; \mathrm{T}_{1}=$ One row of millet alternating with one row of cowpea (1M:1C); $\mathrm{T}_{2}=\mathrm{Two}$ rows of millet alternating with one row of cowpea (2M:1C); $\mathrm{T}_{3}=$ One row of millet alternating with two rows of cowpea $(1 \mathrm{M}: 2 \mathrm{C}) ; \mathrm{T}_{4}=$ Sole millet; $\mathrm{T}_{5}=\mathrm{Sole}$ cowpea. Means not sharing the same letter in common differ significantly at $5 \%$ probability level. 
matter yield of cowpea $\left(t \mathrm{ha}^{-1}\right)$ were significantly affected by intercropping of pearl millet with cowpea.

\section{Plant population $\left(\mathrm{m}^{-2}\right)$ of pearl millet}

The data regarding plant population of pearl millet given in Table 1. Total numbers of plants have a significant effect on final yield of crop. This quantity varies with respect to different planting pattern for example this quantity varies in case of intercropping. On the basis of results it is revealed that plant population differs significantly in different treatments. The treatment in which pearl millet was sown alone with a distance of $30 \mathrm{~cm}$ produced maximum no. of plants per meter square which are $\left(88.33 \mathrm{~m}^{-2}\right)$. The treatment $\mathrm{T}_{2}$ (two rows of millet alternating with one row of cowpea) produced 58.66 plants per meter square $\mathrm{Ta}$ ble 1 . In the same way the treatment $T_{1}$ (one row of millet alternating with one row of cowpea) gave 44 plants per meter square. And minimum no. of plants (29.66 per meter square) was produced by treatment $\mathrm{T}_{3}$. Higher number of plants in treatment $\mathrm{T}_{4}$ was due to sole sowing of millet in that plot.

The treatments where intercropping was done, higher number of plants were produced in treatment $T_{2}$ where two rows of millet were sown with one row of cowpea. This difference in the number of plants was may be due to competition within crops for sources like light, moisture and many others. Results of this study were same as of [25] who said that when maize was sown alone then it gives maximum number of plants.

\section{Plant height $(\mathrm{cm})$ of pearl millet}

Plant height has important part in determining the yield of fodder crops that may be affected due to intercropping. Data relating plant height $(\mathrm{cm})$ of pearl millet is presented in Table 1 that shows significant differences among various treatments with respect to height of plants. The plants in treatment $\mathrm{T}_{4}$ (sole millet) gave maximum height $\left(250.33 \mathrm{~cm}\right.$ ). It is followed by treatment $T_{2}$ (two rows of pearl millet alternating with one row of cowpea) which shows plant height $\left(246.33 \mathrm{~cm}\right.$ ). The treatment $\mathrm{T}_{3}$ (one row of millet alternating with two rows of cowpea) produced plants of $241 \mathrm{~cm}$ height and it is at par with treatment $\mathrm{T}_{1}$ (one row of millet alternating with one row of cowpea).

If we say that why treatment $T_{4}$ plants where sole millet was sown gave maximum height then it may be due to no competition due to any other crop in that treatment. The plants in this treatment use the resources available at that time fully and gave maximum height. Among treatments of intercropping treatment $\mathrm{T}_{2}$ (two rows of pearl millet alternating with one row of cowpea) plant gave maximum height $(246.33 \mathrm{~cm})$. This height was less than the height of plants of treatment $\mathrm{T}_{4}$, it may be due to the influence of legume crop that act as a suppressive crop.

It is revealed that due to intercropping of legumes there was a remarkable reduction in the height of plants of pearl millet which shows the suppressive influence of cowpea crop thus there is reduction in height. These consequences are in line with [25] who said when maize is intercropped in legumes then sole ma- 
ize shows the maximum height when compared with intercrop treatments. [12] also said that there was clear variation in the height of sorghum plants when it was intercropped with other crops.

\section{Leaf area $\left(\mathrm{cm}^{2}\right)$ of pearl millet}

Leaf area is equal to the product of length and width of leaf. It can be influenced due to difference in the fertility of soil and due to prevailing environmental conditions. Nutritional importance of leaves is greater than stems as animals mostly like to eat leaves of crops rather than stems. Besides other factors which contribute in the final yield, leaf area is one of those factors which affect the yield of crop.

Data of the leaf area of plants in given in Table 1 and it shows significant effect of intercropping on leaf area of plants of pearl millet. The treatment $\mathrm{T}_{4}$ (sole millet) plants gave highest leaf area $\left(2415 \mathrm{~cm}^{2}\right.$ ). Then next $\mathrm{T}_{2}$ (two rows of millet alternating with one row of cowpea) produced plants of leaf area of $\left(2250 \mathrm{~cm}^{2}\right)$ and treatment $\mathrm{T}_{1}$ (one row of millet alternating with one row of cowpea) produced plants of leaf area $\left(2186 \mathrm{~cm}^{2}\right.$ ). The plants of treatment $\mathrm{T}_{3}$ (one row of millet alternating with two rows of cowpea) gave minimum leaf area $\left(2103 \mathrm{~cm}^{2}\right)$. In treatments of intercropping $\mathrm{T}_{2}$ (two rows of millet alternating with one row of cowpea) gave maximum leaf area.

Differences among different treatments in leaf area were may be due to the improper penetration and absorption of light. It may be due to the improper circulation of air. As in the experiment all plots were sown with $30 \mathrm{~cm}$ distance so intercropping of legumes affected the leaf area of plants.

\section{Leaf to stem ratio of pearl millet}

It is an important factor that determines the quality of plants as leaves being more digestive and favorite food for animals than stems. It affects by the application of nitrogen. Intercropping of legumes directly affect the leaf to stem ratio. Data relating to leaf to stem ratio is given in Table 1. It is obvious from that table that treatment $\mathrm{T}_{3}$ (one row of millet alternating with two rows of cowpea) gave maximum leaf to stem ratio $(0.26)$ that is tracked by $\mathrm{T}_{1}$ (one row of millet alternating with one row of cowpea) where leaf to stem ratio was (0.22). The treatment $\mathrm{T}_{2}$ (two rows of millet alternating with one row of cowpea) shows leaf to stem ratio (0.19) and treatment $\mathrm{T}_{4}$ (sole millet) showed minimum leaf to stem ratio $(0.16)$.

\section{Stem diameter $(\mathrm{cm})$ of pearl millet}

It is a significant factor regarding the yield but there is inverse relationship of stem diameter with quality of fodder. Quality will be lower if the stem diameter will be greater. Data of stem diameter of pearl millet is given in Table 1. Data showed that intercropping significantly affected stem diameter. The treatment $\mathrm{T} 1$ (one row of millet alternating with one row of cowpea) produced stems of $1.12 \mathrm{~cm}$ diameter and it was at par with treatment $\mathrm{T}_{2}$ (two rows of millet alternating with one row of cowpea). The treatment $\mathrm{T}_{3}$ (one row of millet alternating with two rows of cowpea) produced stems of $1.08 \mathrm{~cm}$ diameter. This treatment produced very thin stems. The treatment $\mathrm{T}_{4}$ (sole millet) produced thicker stems 
of $1.21 \mathrm{~cm}$ diameter. The treatment $\mathrm{T}_{3}$ (one row of millet alternating with two rows of cowpea) produced thinner stem; this might be due to major portion of legume crop in this treatment and this effects the quality of crop.

These results in line with [26] who said that when sorghum was intercropped then there was a significant difference in stem diameter of sorghum. On the other hand these results are not similar with [27]. They found that when soybean was sown under various arrangements then non-significant difference was there for stem diameter. These variations may be due to difference in fertility level, environmental conditions, soil conditions and many other factors.

\section{Green forage yield ( $\left.\mathrm{tha}^{-1}\right)$ of pearl millet}

Fresh forage yield is affected by various innate factors. It may vary with different climatic factors which directly affects the growth of a plant and then leading to forage yield at an end. Data about the yield of pearl millet is given in Table 2 that clearly shows that intercropping has influenced significantly the fodder yield of pearl millet. Highest forage yield $\left(44 \mathrm{t} \mathrm{ha}^{-1}\right.$ ) was recorded in $\mathrm{T}_{4}$ (sole cowpea). The treatment $\mathrm{T}_{2}$ (two rows of millet alternating with one row of cowpea) give forage yield $\left(29.10 \mathrm{t} \mathrm{ha}^{-1}\right)$ and treatment $\mathrm{T}_{1}$ (one row of millet alternating with one row of cowpea) give forage yield $\left(22.06 \mathrm{t} \mathrm{ha}^{-1}\right)$, respectively. The minimum yield (14.62 $\mathrm{t} \mathrm{ha}^{-1}$ ) was perceived in treatment $\mathrm{T}_{3}$ (one row of millet alternating with two rows of cowpea).

It is clear from the table that from intercrop treatments, $\mathrm{T}_{2}$ (two rows of millet alternating with one row of cowpea) gave maximum forage yield. When sorghum is intercropped with legumes then legumes act as a suppressive crop, this was stated by [3]. These inferences were not in line with [28] who said that when sorghum was intercropped with cowpea then sorghum shows greater yield due to intercropping.

\section{Green forage yield ( $\mathrm{t} \mathrm{ha} \mathrm{h}^{-1}$ ) of cowpea}

Performance of any crop can be judged by knowing the yield it produces. Farmers mostly like to cultivate high yielding forages for their animals or for commercial purpose. Data concerning forage yield of cowpea is given in Table 2 that shows that intercropping has a significant influence on the yield of cowpea. Highest forage yield $\left(33.53 \mathrm{t} \mathrm{ha}^{-1}\right.$ ) of cowpea was recorded in treatment $\mathrm{T}_{5}$ (sole cowpea) after that $\mathrm{T}_{3}$ (one row of millet alternating with two rows of cowpea) shows forage yield of $\left(22.3 \mathrm{tha}^{-1}\right)$.

Within various treatments of intercropping treatment $\mathrm{T}_{3}$ (one row of millet alternating with two rows of cowpea) gave maximum yield $\left(22.3 \mathrm{t} \mathrm{ha}^{-1}\right)$ and treatment $\mathrm{T}_{2}$ (two rows of millet alternating with one row of cowpea) give minimum yield (11.13 $\left.\mathrm{t} \mathrm{ha}^{-1}\right)$. This difference in yield is may be due to respective proportion of cowpea crop used in the respective treatment. [29] said that when sorghum was intercropped with cowpea then it produces higher yield of forage and the same was said by [28].

Green forage yield ( $\mathrm{t} \mathrm{ha} \mathrm{h}^{-1}$ ) of mixed forage (pearl millet and cowpea)

Total green forage yield is equal to the addition of yield produced by main 
crop and intercrop and it was greatly influenced due to different sowing methods and different mixtures of crops being grown with each other. Data regarding mixed forage yield was given in Table 2. Within various treatments of intercropping, treatment $\mathrm{T}_{2}$ (two rows of millet alternating with one row of cowpea) give maximum forage yield $\left(40.23 \mathrm{t} \mathrm{ha}^{-1}\right)$. After this treatment $\mathrm{T}_{1}$ (one row of millet alternating with one row of cowpea) and treatment $\mathrm{T}_{3}$ (one row of millet alternating with two rows of cowpea) give mixed forage yields $\left(38.80 \mathrm{tha}^{-1}\right.$ and $36.90 \mathrm{t} \mathrm{ha}^{-1}$, respectively). Thus the combination where two of pearl millet is sown with one row of cowpea produced maximum mixed green forage yield.

Dry matter yield $\left(\mathrm{t} \mathrm{ha}^{-1}\right)$ of pearl millet

Dry matter is produced in plants due to the photosynthetic activity of plants and it is a direct measure of the efficiency of this system. Data relating dry matter yield of pearl millet is given in Table 2 which depicts significant variations. Higher dry matter yield $\left(10.91 \mathrm{t} \mathrm{ha}^{-1}\right)$ was produced by $\mathrm{T}_{4}$ (sole millet) and after this treatment $\mathrm{T}_{2}$ (two rows of millet alternating with one row of cowpea) give dry matter yield $\left(7.24 \mathrm{t} \mathrm{ha}^{-1}\right)$.

Within various treatments of intercropping, $\mathrm{T}_{2}$ (two rows of millet alternating with one row of cowpea) give maximum dry matter yield $\left(7.24 \mathrm{t} \mathrm{ha}^{-1}\right)$ of pearl millet. These findings are supported by [30]. They reported that when maize was sown with mixed crops then maximum dry matter yield was observed in sole maize. These results are not in line with [31]. They found that when sorghum was intercropped with cowpea then their intercrop combinations produced higher yield of fresh and dry matter as compared to their sole combinations. These variations are may be due to variation in fertility level of the soil, change in species selected and prevailing environmental conditions.

\section{Dry matter yield $\left(\mathrm{t} \mathrm{ha}^{-1}\right)$ of cowpea}

Dry matter is produced in plants due to the photosynthetic activity of plants and it is a direct measure of the efficiency of this system. Data relating dry matter yield of pearl millet is shown in Table 2 which showed significant variations. The maximum dry matter yield ( $\left.10.91 \mathrm{t} \mathrm{ha}^{-1}\right)$ was produced by $\mathrm{T}_{4}$ (sole millet) and after this treatment $T_{2}$ (two rows of millet alternating with one row of cowpea) give dry matter yield $\left(7.24 \mathrm{t} \mathrm{ha}^{-1}\right)$.

Within various treatments of intercropping, $\mathrm{T}_{2}$ (two rows of millet alternating with one row of cowpea) give maximum dry matter yield $\left(7.24 \mathrm{t} \mathrm{ha}^{-1}\right)$ of pearl millet. These findings are supported by [30]. They reported that when maize was sown with mixed crops then maximum dry matter yield was observed in sole maize. These results are not in line with [31]. They found that when sorghum was intercropped with cowpea then their intercrop combinations produced higher yield of fresh and dry matter as compared to their sole combinations. These variations are because of variation in fertility level in the soil, change in species selected and prevailing environmental conditions.

Dry matter yield $\left(\mathrm{t} \mathrm{ha}^{-1}\right)$ of mixed forage (pearl millet + cowpea)

Total dry yield is equal to the addition of dry yield of pearl millet and cowpea. 
Data regarding dry matter yield of mixed forage was given in Table 2 which showed variations in the treatments significantly. Maximum dry matter yield (10.91 $\mathrm{t} \mathrm{ha}^{-1}$ ) was perceived in treatment $\mathrm{T}_{4}$ (sole millet). After this treatment $\mathrm{T}_{2}$ (two rows of millet alternating with one row of cowpea) produced dry matter yield $\left(9.68 \mathrm{t} \mathrm{ha}^{-1}\right)$.

Within various treatments of intercropping, it is evident than treatment $T_{2}$ (two rows of millet alternating with one row of cowpea) give maximum total dry matter yield $\left(9.68 \mathrm{t} \mathrm{ha}^{-1}\right.$ ). It was then tracked by treatment $\mathrm{T}_{1}$ (one row of millet alternating with one row of cowpea) and treatment $\mathrm{T}_{3}$ (one row of millet alternating with two rows of cowpea) producing dry matter yield $\left(9.07 \mathrm{t} \mathrm{ha}^{-1}\right.$ and $8.33 \mathrm{t} \mathrm{ha}^{-1}$, respectively). These consequences are supported by [30]. They said that maize gives higher dry matter yield in sole sowing of maize rather than where it was sown mixed with other crops.

Crude protein (\%) of mixed forage (pearl millet + cowpea)

Quality of fodder is directly determined by the presence of crude protein contents in that fodder. As we know that pearl millet is low in the amount of crude protein contents, so in order to increase the amount of protein in total fodder, pearl millet is intercropped with any legume crop so that overall contents can be improved. It does not mean the intercropping of legume will increase the protein contents of pearl millet instead it will increase the protein contents of mixed fodder.

Data regarding Crude protein (\%) of mixed forage given in Table 3 shows variations in the protein contents of treatments due to intercropping of legume crop with pearl millet. The treatment $\mathrm{T}_{3}$ exhibited higher protein contents (14.56\%) where one row of millet was sown with two rows of cowpea. The treatments $\mathrm{T}_{1}$ (1M:1C) and $\mathrm{T}_{2}$ (2M:1C) exhibited the same crude protein contents $(12.96 \%$ and $11.23 \%$, respectively). The treatments where intercropping was done exhibit higher protein contents than sole crops. This is due to higher

Table 3. Growth and yield related quality parameters of pearl millet and cowpea as influenced by intercropping of millet with cowpea.

\begin{tabular}{cccc}
\hline Treatments & $\begin{array}{c}\text { Crude protein (\%) } \\
\text { of mixed forage }\end{array}$ & $\begin{array}{c}\text { Crude fiber (\%) } \\
\text { of mixed forage }\end{array}$ & Ash (\%) of mixed forage \\
\hline $\mathrm{T}_{1}$ & 12.96 & 22.73 & 17.36 \\
$\mathrm{~T}_{2}$ & 13.50 & 24.63 & 19.66 \\
$\mathrm{~T}_{3}$ & 14.56 & 23.23 & 18.16 \\
$\mathrm{~T}_{4}$ & 11.06 & 30.13 & 21.26 \\
$\mathrm{~T}_{5}$ & 11.23 & 21.56 & 16.06 \\
LSD & 0.8885 & 0.9092 & 1.1274 \\
F Value & $30.34^{*}$ & $144.98^{\star *}$ & $34.17^{\star *}$ \\
\hline
\end{tabular}

${ }^{*}=$ Significant at $p \leq 0.05 ;{ }^{* *}=$ Significant at $p \leq 0.01 ; \mathrm{T}_{1}=$ One row of millet alternating with one row of cowpea (1M:1C); $\mathrm{T}_{2}=$ Two rows of millet alternating with one row of cowpea (2M:1C); $\mathrm{T}_{3}=$ One row of millet alternating with two rows of cowpea (1M:2C); $\mathrm{T}_{4}=$ Sole millet; $\mathrm{T}_{5}=$ Sole cowpea. Means not sharing the same letter in common differ significantly at $5 \%$ probability level. 
protein percentage of legume crop. [32] found that there was increase in the amount of protein contents in intercrop treatments as compared with sole maize. [33] reported that to increase the protein contents of cereals, intercropping of cereals with legumes should be done. [29] found that there was an increase in the amount of protein contents in intercropping treatments as compared with sole maize.

There is an increase in the amount of protein contents of fodder when intercropped with legumes found by [34]. [35] also said increase in the amount of protein contents when cereals are intercropped with legumes as compared with cereals alone.

\section{Crude fiber (\%) of mixed forage (pearl millet + legumes)}

There is an inverse relation of crude fiber contents with quality of forage. If forage is having lower amount of crude fiber then it is of best quality as higher crude fiber contents lead to lower digestibility.

Data relating to the crude fiber\% is given in Table 3 which show variation among treatments. The treatment $\mathrm{T}_{4}$ where sole millet was sown exhibited higher crude fiber contents $(30.13 \%)$ as compared to all other treatments. The treatment $\mathrm{T}_{2}$ where two rows of millet are sown with one row of cowpea exhibited crude fiber\% (24.63). The treatment $\mathrm{T}_{1}$ is at par with $\mathrm{T}_{2}$. The treatment $\mathrm{T}_{5}$ where cowpea was sown alone exhibited lowest crude fiber\% (21.56).

There are significant variations in the amount of CF\% when sown with legumes found by [36]. They found that when sorghum was intercropped with cowpea then sole sorghum exhibited higher amounts of crude fiber. Sole sorghum exhibited higher crude fiber contents than sown with guara [26].

\section{Ash (\%) of mixed forage (pearl millet + cowpea)}

Data regarding ash contents is given in Table 3. The treatment $\mathrm{T}_{4}$ where sole millet was sown showed maximum ash contents (21.26\%) as compared to all other treatments. The treatment $\mathrm{T}_{2}$ where two rows of millet are sown with one row of cowpea showed ash contents $\left(19.66 \%\right.$ ). The treatment $\mathrm{T}_{1}$ (one row of millet alternating with one row of cowpea) is at par with $\mathrm{T}_{3}$. The treatment $\mathrm{T}_{5}$ (sole cowpea) shown minimum ash contents (16.06\%).

These results are not in line with [36]. They said that when sorghum was sown rice bean, then there was high ash percentage. These variations in results are may be due to variation in soil fertility, environmental conditions and choice of species.

\section{Conclusion}

Keeping in view the result of above experiment, it is concluded that both forage quality and quantity of forage millet mixed with cowpea can be obtained by growing two rows of millet with one row of cowpea (2M:1C).

\section{Conflicts of Interest}

The authors declare no conflicts of interest regarding the publication of this paper. 


\section{References}

[1] Chaudhary, A.R. (1983) Maize in Pakistan. Agriculture Research Coordination Board, University of Agriculture Faisalabad, Faisalabad, 85-86.

[2] Iqbal, A., Ayub, M., Akbar, N. and Ahmad, R. (2006) Growth and Forage Yield Response of Maize-Legume Mixed Cropping to Different Sowing Techniques. Pakistan Journal of Agricultural Sciences, 43, 126-130.

[3] Singh, P.K. and Jadhav, A.S. (2003) Intercropping of Sorghum with Pigeonpea, Groundnut and Soybean under Varying Planting Geometry. Indian Journal of Dryland Agricultural Research and Development, 18, 126-129.

[4] Anil, L., Park, J., Phipps, R.H. and Miller, F.A. (1998) Temperate Intercropping of Cereals for Forage: A Review of the Potential for Growth and Utilization with Particular Reference to the UK. Grass and Forage Science, 53, 301-317. https://doi.org/10.1046/j.1365-2494.1998.00144.x

[5] Iqbal, A., Ayub, M., Zaman, H. and Ahmed, R. (2006) Impact of Nutrient Management and Legume Association on Agro-Qualitative Traits of Maize Forage. Pakistan Journal of Botany, 38, 1079-1084.

[6] Hauggard-Nielsen, H. and Jensen, E.S. (2001) Evaluating Pea and Barley Cultivars for Complimentary in Intercropping Different Levels Soil N Availability. Field Crops Research, 72, 185-196. https://doi.org/10.1016/S0378-4290(01)00176-9

[7] Agegnehu, G., Ghizam, A. and Sinebo, W. (2006) Yield Performance and Land Use Efficiency of Barley and Faba Bean Mixed Cropping in Ethopian High Lands. European Journal of Agronomy, 25, 202-207. https://doi.org/10.1016/j.eja.2006.05.002

[8] Tsubo, M. Walker, S. and Ogindo, H.O. (2005) A Simulation Model of Cereal-Legume Intercropping Systems for Semi-Arid Regions. Field Crops Research, 93, 23-33. https://doi.org/10.1007/s00374-004-0737-3

[9] Lithourgidis, A.S., Vasilakoglou, I.B., Dhima, K.V., Dordas, C.A. and Yiakoulaki, M.D. (2006) Forage Yield and Quality of Common Vetch Mixtures with Oat and Triticale in Two Seeding Ratios. Field Crops Research, 99, 106-113. https://doi.org/10.1016/j.fcr.2006.03.008

[10] Eaglesham, A.R.J., Ayanaba, A., Rao, V.R. and Eskew, D.C. (1981) Improving the Nitrogen Nutrition of Maize by Intercropping with Cowpea. Soil Biology and Biochemistry, 13, 231-234.

[11] Shen, Q.R. and Chu, G.X. (2004) Bi-Directional Nitrogen Transfer in an Intercropping System of Peanut with Rice Cultivated in aerobic Soil. Biology and Fertility of Soils, 40, 81-87. https://doi.org/10.1007/s00374-004-0737-3

[12] Ahmad, A., Ahmad, R., Mahmood, N. and Tanveer, A. (2007) Performance of Forage Sorghum Intercropped with Forage Legumes under Different Planting Patterns. Pakistan Journal of Botany, 39, 431-439.

[13] Ayaz, S., Shah, P., Sharif, H.M. and Ali, I. (1999) Yield, Yield Components and Other Important Agronomic Traits of Wheat as Affected by Seed Rate and Planting Geometry. Sarhad Journal of Agriculture, 15, 255-261.

[14] Hussain, I., Jatoi, S.A., Sayal, O. and Baloch, S.A. (1999) Green Fodder Yield and Land Equivalent Ratio of Sorghum Legume Association. Pakistan Journal of Biological Science, 3, 175-176.

[15] Keshwa, G.L. and Yadav, M.L. (1989) Effect of Nitrogen and Cutting Management on Growth and Fodder Yield on Bajra Varieties. Haryana Journal of Agronomy, 5, 188-190.

[16] Ayub, M., Nadeem, M.A., Tanveer, A. and Husnain, A. (2002) Effect of Different 
Levels of Nitrogen and Harvesting Time on Grmith, Yield and Quality of Sorghum Fodder. Asian Journal of Plant Sciences, 4, 304-307.

[17] Beck, P.A., Hutchison, S., Gunter, S.A., Losi, T.C., Stewart, C.B., Capps, P.K. and Phillips, J.M. (2007) Chemical Composition and In-Situ Dry Matter and Fiber Disappearance of Sorghum X Sudan Grass Hybrids. Journal of Animal Science, 85, 545-555. https://doi.org/10.2527/jas.2006-292

[18] Padhi, A.K. (2001) Effect of Vegetable Intercropping on Productivity, Economics and Energetics of Maize (Zea mays). Indian Journal of Agronomy, 46, 204-210.

[19] Pereira Filho, I.A., Oliveira, A.C., De Cruz, J.C. and Oliveria, A.C.E. (2000) Maize and Common Bean Intercropping System with Double and Single Maize Rows. Pesquisa Agropernaria Brasilira, 35, 5-9.

[20] Padhi, A.K. and Panigrahi, R.K. (2006) Effect of Intercrop and Crop Geometry on Productivity, Economics, Energetics and Soil-Fertility Status of Maize Based Intercropping Systems. Indian Journal of Agronomy, 51, 174-177.

[21] Oseni, T.O. (2010) Evaluations of Sorghum-Cowpea Intercrop Productivity in Savanna Agro-Ecology Using Competition Indices. The Journal of Agricultural Science, 2, 229-234.

[22] Abdullah, M. and Chaudhry, M.T. (1996) Improved Fodder and Seed Production in Central Irrigated Punjab. Proceedings of National Conference on the Improvement Production and Utilization of Fodder Crops in Pakistan, Islamabad, 25-27 March 1996, 55-62.

[23] Alemseged, Y.B., King, G.W., Coppock, L.R. and Tothill, J.C. (1996) A Preliminary Investigation of the Potential for Maize-Legume Intercropping in the Semi-Arid Area of Sidamo Region, Ethopia. II. Legume Response. South African Journal of Plant and Soil, 13, 125-130. https://doi.org/10.1080/02571862.1996.10634388

[24] Steel, R.G.D., Torrie, J.H. and Dickey, D.A. (1997) Principles and Procedures of Statistics. A Biological Approach. 3rd Edition, McGraw Hill Book Co., New York, 352-358.

[25] Ibrahim, M., Rafiq, M., Sultan, A., Akram, M. and Goheer, A.R. (2006) Green Fodder Yield and Quality Evaluation of Maize and Cowpea Sown Alone and in Combination. Journal of Agricultural Research, 44, 15-21.

[26] Ayub, M. and Shoaib, M. (2009) Studies on Fodder Yield and Quality of Sorghum Grown Alone and in Mixture with Guara under Different Planting Techniques. $\mathrm{Pa}$ kistan Journal of Agricultural Research, 46, 25-29.

[27] Hong, K.S., Lee, H.J. and Rhyu, J.H. (1987) Response of Maize and Soybean Canopy Structure, Dry Matter and Yield to Intercropping. The Korean Journal of Crop Science, 32, 357-368.

[28] Ayisi, K.K., Mpori, M.S. and Van-Den-Berg, J. (2001) Grain Yield Response and Chile partillus Infestation in Diverse Sorghum Cowpea Intercrop Management. South African Journal of Plant and Soil, 18, 39-42. https://doi.org/10.1080/02571862.2001.10634399

[29] Krishna, A., Raikhelkar, S.V. and Reddy, A.S. (1998) Effect of Planting Pattern and Nitrogen on Fodder Maize Intercropped with Cowpea. Indian Journal of Agrono$m y, 43,237-240$.

[30] Khot, R.B., Desale, J.S., Pisal, A.A. and Patil, S.K. (1992) Assessment of Forage Productive Potential of Maize (Zea mays) with Forage Legumes in Various Planting Systems. Indian Journal of Agronomy, 37, 343-345.

[31] Chellaiah, N. and Earnest, J. (1994) Fodder Production of Cereal Legume Mixture. 
Livestock Advisor, 19, 15-18.

[32] Marchiol, L., Miceli, F., Eiosa, M. and Zerbi, G. (1992) Intercropping of Soybean and Maize for Silage in Nothern Italy. Effect of Nitrogen Level and Plant Density on Growth, Yield and Protein Contents. European Journal of Agronomy, 1, 207-211. https://doi.org/10.1016/S1161-0301(14)80071-3

[33] Ngongoni, N.T., Mwale, M., Mapiye, C., Moyo, M.T., Hamudikuwada, H. and Titterton, M. (2007) Evaluation of Cereal Legume Intercropped Forages for Small Holder Dairy Production in Zimbabwe. Livestock Research for Rural Development, 19, 145-148.

[34] Ram, S.N. and Singh, B. (2003) Physiological Growth Parameters, Forage Yield and Nitrogen Uptake of Sorghum (Sorghum bicolor) as Influenced with Legume Intercropping, Harvesting Time and Nitrogen Level. Indian Journal of Agronomy, 18, 167-172.

[35] Reddy, G.V.N., Reddy, M.R., Rangamannar, K.T.V. and Khan, M.H. (1986) Effect of Planting Geometry and Legumes and Cowpea Intercropping on Forage Yield and Nutritional Potential for Sheep. Indian Journal of Animal Nutrition, 3, 254-257.

[36] Ayub, M., Tanveer, A., Nadeem, M.A. and Shah, S.M.A. (2004) Studies on the Fodder Yield and Quality of Sorghum Grown Alone and in Mixture with Rice Bean. Pakistan Journal of Life and Social Sciences, 2, 46-48. 